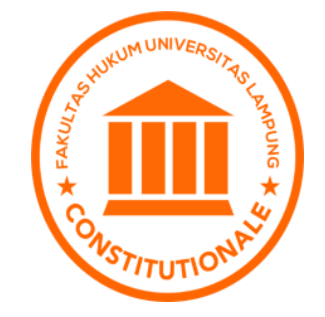

\title{
CONSTITUTIONALE
}

Volume 2 Issue 1, January-June 2021: PP: 13-26

Faculty of Law, Universitas Lampung, Bandar Lampung,

Indonesia.

http://jurnal.fh.unila.ac.id/index.php/constitutionale

P-ISSN: 2723-2492 E-ISSN: 2745-9322

\section{The Omnibus Law in the Perspective of Responsive Law and its Impact on Indonesia's Economy}

\author{
Renaldy Eka Putra
}

renaldyekaputra2@gmail.com

UIN Raden Intan Lampung, Indonesia

Submitted: 5 January 2021; Reviewed: 4 February 2021; Accepted: 20 April 2021.

\section{Article's Information}

Keywords: Omnibus; Law; Responsive.

DOI:

https://doi.org/10.25041/constitutionale.v2i1.2199

\section{Abstract}

The government passed the Job Creation Law using the Omnibus Law concept, to be used to build the Indonesian economy to attract investors to invest in Indonesia. The Job Creation Law has several clusters in it, one of which regulates employment. Therefore this paper aims to analyze in-depth the ratification of the Omnibus Law policy using a responsive legal approach (Based on Law No.12 of 2011 concerning the Formation of Laws and Regulations) and looking empirically at the obstacles in creating employment in Indonesia, the correlation between the Job Creation Law and the principle of justice in the era of the Covid-19 pandemic. The method used in this paper is normative-juridical with a statute approach and a conceptual approach, then content analysis, which describes and analyzes the scope of legal theory. This paper's type of data is secondary data obtained from literature, books, journals and articles, official reports of National Media related to 


\section{A. Introduction}

Jokowi-ma'ruf Amin's administration (20/10/2020) has been a year old. The winning pair for the 2019 Presidential Election were sworn in at the MPR Plenary Session led by MPR President Bambang Soesatyo at the DPR Senayan Building, Jakarta. At least there are five priority work programs that Jokowi revealed during the inauguration. Of course, the five programs were implemented by Jokowi long before the Coronavirus (Covid-19) hit Indonesia and several countries. It has been a year since Jokowi-Ma'ruf opened the way. Indeed, the current program is still below expectations. This program that has not been running optimally is due to the coronavirus outbreak that has hit Indonesia since last March. ${ }^{1}$

Jokowi-Ma'ruf's main priority is to develop superior and quality human resources who master science and technology. ${ }^{2}$ To achieve this, Jokowi stated that endowment funds require a large amount of human resource management. Second, infrastructure development is still Jokowi's priority agenda in his second term. In particular, it connects production areas and access to tourist areas to boost the city's economy. Third, the Omnibus Creation Law simplifies a complex set of rules. Jokowi immediately asked the the Indonesia's House of Representatives or Dewan Perwakilan Rakyat (DPR) to develop a Collective Law, a comprehensive law that can revise many laws. ${ }^{3}$ The goal is to facilitate issuing licenses for micro, Small and Medium Enterprises (SME). Besides that, it is also to create employment opportunities in Indonesia. Fourth, simplifying the bureaucracy and, ultimately, economic transformation must be carried out in the second period of his leadership. He appealed to all parties to move from dependence on natural resources to modern industry competitiveness and services. ${ }^{4}$

Based on Indonesia's 2045 vision, the Indonesian economy is expected to grow $5.7 \%$ per year during the 2016-2045 period by implementing structural reforms, leveraging demographic premiums and technological advances, and increasing economic competitiveness. ${ }^{5}$ With this aim, Indonesia is expected to become a high-income country by 2036 and have the fifth largest GDP in the world by 2045. High and inclusive economic growth will bring the number of the middle class to around $70 \%$. Indonesian population in 2045. ${ }^{6}$ However, efforts to advance Indonesia's economy and competitiveness in line with Vision 2045 present several challenges, including relatively low competitiveness, slowing economic growth, and uneven economic growth. These three problems are caused, among

\footnotetext{
1 Putra Antoni, "PENERAPAN OMNIBUS LAW DALAM UPAYA REFORMASI REGULASI," Legislasi Indonesia 17, no. 1 (2020), https://e-jurnal.peraturan.go.id/index.php/jli/article/view/602.

2 Adhi Setyo Prabowo, Andhika Nugraha Triputra, and Yoyok Junaidi, "Politik Hukum Omnibus Law Di Indonesia," Pamator Journal 13, no. 1 (April 4, 2020): 1-6, https://doi.org/10.21107/pamator.v13i1.6923.

3 Henry Donald and Lbn Toruan, "PEMBENTUKAN REGULASI BADAN USAHA DENGAN MODEL OMNIBUS LAW,” To-Ra, vol. 3, May 16, 2017, http://katadata.co.id/berita/2017/05/09/jelang.

${ }^{4}$ Gesuri.id, 5 prioritas kerja Jokowi-Ma'kruf, di akses di https://www.gesuri.id/grafis/5-prioritas-kerja-jokowima-ruf-b1WovZnDw,

5 Ahmad Ulil, Sakti Lazuardi, and Ditta Chandra Putri, “Arsitektur Penerapan Omnibus Law Melalui Transplantasi Hukum Nasional Pembentukan Undang-Undang," Jurnal Ilmiah Kebijakan Hukum 14, no. 1 (March 27, 2020): 1, https://doi.org/10.30641/kebijakan.2020.v14.1-18.

${ }^{6}$ Kementerian Perencanaan Pembangunan Nasional/Badan Perencanaan Pembangunan Nasional, "Ringkasan Eksekutif Visi Indonesia 2045," (Oktober 2018), pg. 5.
} 
others, by the unfavorable business climate in Indonesia and the weak and imbalanced investment in Indonesia. ${ }^{7}$

Compared to other Asian countries such as Vietnam, Taiwan, Bangladesh, and South Korea, Indonesia is not an attractive investment choice. According to The Washington Post, 1 in 50 multinational companies has announced plans to shift production from China after the Sino-American trade war. Indonesia does not benefit much from the migration of foreign companies from China. ${ }^{8}$ Based on data from the Investment Coordinating Board or Badan Koordinasi Penanaman Modal (BKPM), investment increased 5.3\% to 195.1 trillion rupees in the first quarter of 2019. This achievement was Indonesia's lowest achievement during the 2014-2019 period. Even though it rose from the first quarter of 2018, growth was still far from the government's expectations. ${ }^{9}$ When the government promised to find a solution to the uncertainty of investment in job creation in Indonesia, Jokowi, as prime minister, announced on 20 October 2019 his plan to make a law using the omnibus method. This law will repeal and change several rules through a new law. Jokowi said all forms of regulatory restrictions must be simplified and reduced. ${ }^{10}$ Following the president's direction, the government drafted a law to create jobs using the omnibus method. On 13 February 2020, the government submitted a Job Creation Bill to the DPR. The discussion of the bill in the DPR began on 2 April 2020.From the start, the government's plan received a lot of public attention. However, amid fears of the outbreak of the 2019 coronavirus (COVID -19), Indonesia's House of Representatives or Dewan Perwakilan Rakyat (DPR) passed the law inviting the Omnibus. The Job Creation Law at the closing of the 2020-2021 session on 5 October 2020. Two of the nine party factions refused to ratify it, such as the Partai Keadilan (UKM) Kaya, the Partai Demokrat (PD). Since being adopted by the DPR, the conflict's potential is currently in the hands of the president. The president has 30 days to delete or not delete following Article 73 of Law No. 12 of 2011 concerning the formation of laws and regulations. Of course, the public is looking forward to the presidential election and its ratification results on 2 November 2020. President Joko Widodo signed the Job Creation Law or Collective Law on the same day it was signed by the Minister of Law and Human Rights, Yasonna H. Laoly. This law is published in the Official Gazette of the Republic of Indonesia 2020 No. 45.

The Omnibus law is a comprehensive law that regulates various provisions in various industrial sectors compiled as one law. The goal is to strengthen the economy by increasing competitiveness, creating jobs, and facilitating business in Indonesia. As a result of President Joko Widodo describing his vision for Indonesia in 2045, he produced a quoted speech in English: "Our dream is, by 2045, Indonesia's gross domestic product will reach the US \$ 7 trillion. Indonesia is wrong. One of the five largest economies in the world with a poverty rate close to zero percent. That's what we have. The government admits it has to tackle the problem of excessive regulation in Indonesia to achieve this vision". The bureaucracy has long been held, the country's growth discourages foreign investment. The Indonesian economy is currently ranked 73 out of 190 countries on World Bank President Joko Widodo,

\footnotetext{
${ }^{7}$ Stephanie juwana dkk, sistem dan praktik omnibus law di berbagai negara dan analisis ruu cipta kerja dari perspektif good legislation making. ( Jakarta Pusat, DKI Jakarta: Indonesia Ocean Justice Initiative, 2020).

${ }^{8}$ Pudjo Utomo, “Omnibus Law : Dalam Perspektif Hukum Responsif," Nurani Hukum 2, no. 1 (May 18, 2020): 33, https://doi.org/10.51825/nhk.v2i1.8168.

9 Kompas.com, "Mengenal Omnibus Law yang akan dibahas pemerintah dan DPR..." https://nasional.kompas.com/read/2019/11/29/13511951/mengenal-omnibus-law-yang-akan- dibahaspemerintah-dan-dpr?page=all.

10 Mochamad Januar Rizki, "Menyoal Ide Omnibus Law dalam Pidato Pelantikan Jokowi," https://www.hukumonline.com/berita/baca/lt5dadb8e0be9fc/menyoal-ide-omnibus-law-dalam-pidato-pelantikanjokowi,
} 
who targets Indonesia to reach $40 .{ }^{11}$ Collaborative law is designed to help achieve this ambitious goal by partially simplifying the complex and sometimes redundant regulatory environment. The law will relax restrictions in 11 key areas, including labor law, investment, business licensing, corporate taxation, and land acquisition. In other words, implementing these measures will make Indonesia a beautiful destination for foreign companies and investors.

Uniquely, the Omnibus Law in Indonesia is present in a critical era where the introduction of Covid-19 has even been reported. On social media, it has been confirmed that the spread of the Corona Covid-19 virus in Indonesia has killed hundreds or thousands of its citizens and forced many to stay at home. The government and parliament have passed laws that would deprive them of their rights (Djalante et al., 2020). Most vulnerable to various epidemic effects. Omnibus law According to the Indonesian government and parliament, job creation is an instrument designed to prevent the country from falling into recession due to the outbreak. ${ }^{12}$ However, trade unions and human rights groups believe that it is none other than state oligarchs' efforts to halt political reforms in a country of 270 million people, most of whom live on the brink of poverty with a population of Covid-19.

There are at least three reasons for such a wrong conclusion. First, the law will only harm citizens, especially those marginalized. Second, the way laws are enforced, debated, and adopted is contrary to international law. Third, the law aims to work openly with economic policy elites and foreign companies throughout Indonesia (Jong, 2020). In the most straightforward and worst analogy, this is a firm license that exploits millions of the country's labor force and seizes natural resources, especially forests depending on local indigenous peoples. ${ }^{13}$ It is assumed that omnibus laws might govern different terms in different industrial sectors in a single law. Based on the disclosure of this data, the researcher will explain the "ratification of the omnibus law in connection with reactive law" in the era of the Covid-19 pandemic and the economy in Indonesia," which is identified in two problems (1) How is the response legal point of view to the enactment of the future omnibus law? (2) How is the omnibus law policy based on social justice principles, which positively impacted the economy during the Covid-19 pandemic approach? This is a normative legal research ${ }^{14}$ Data is collected and analyzed through various available critical legal documents, secondary legal documents, and tertiary legal documents. ${ }^{15}$ The substances are standard or basic rules, regulations, substantial legal rules, and secondary court law consisting of legal materials that provide further explanation. Clarification of the primary legal materials in the form of relevant literature, journal articles, and research. The data was collected through a literature review of books, articles, research results, and legal requirements. Data analysis was carried out descriptively and qualitatively to discuss the formulation of the research problem.

\section{B. Discussion}

\footnotetext{
11 Greenhouse, What Foreign Investors Need to Know About Indonesia's Proposed Omnibus Law https://greenhouse.co/blog/omnibus-law-indonesia/, pada 25 January 2020.

12 Lath, Vivek., Tracy Lee., Khoon Tee Tan., \& Phillia Wibowo. 2020. Despite the Social and Economic Uncertainty and Advance Its Economy and Prepare for Strong Postcrisis Emergence. https://www.mckinsey.com/featured-insights/asia-pacific/with-effort-indonesia-can-emerge-from-the-covid19-crisis-stronger, 25 January 2020.

13 Wicipto Setiadi, "SIMPLIFIKASI REGULASI DENGAN MENGGUNAKAN METODE PENDEKATAN OMNIBUS LAW,” Jurnal Rechts Vinding: Media Pembinaan Hukum Nasional 9, no. 1 (April 27, 2020): 39, https://doi.org/10.33331/rechtsvinding.v9i1.408.

14 Soerjono Soekanto dan Sri Mamudji, Penelitian Hukum Normatif: Suatu Tinjauan Singkat, Cet. 8 (Jakarta: PT RajaGrafindo Persada, 2006).

15 Mohammad Orinaldi, "Relasi Antara Omnibus Law Di Era Pandemi Covid-19 Dan Perekonomian Di Indonesia,” Jurnal Manajemen Dan Sains 5, no. 2 (2020): 269-75, https://doi.org/10.33087/jmas.v5i2.194.
} 


\section{Omnibus Law Policy in Responsive Legal Perspective}

It is a model or theory initiated by Nonet-Selznick in neo-Marxist criticism of liberal legalism. It is assumed by law as an independent institution with a system of rules and objectives, unbiased and correct procedures, fully autonomous. The icon of liberal legalism is legal autonomy. The most apparent form of autonomy is the rule of law. It is believed that because of its autonomous nature, the law can control oppression and maintain its integrity. ${ }^{16}$ Thus, the concept of reactive law can be understood as a selective adaptation to new needs and burdens, which First characterizes, changes in regulatory orientation to principles and goals, second, the importance of a good (populist) popular character both as a legal goal and as a method for achieving it.

Nonet and Selznick illustrate this reactive legal approach with examples of appropriate legal procedures. This concept does not mean anything other than rules of procedure for decision-making under established legal rules in an autonomous legal system. However, the ideal type of reactive law requires a more flexible interpretation of the rule of law related to a particular issue and context. ${ }^{17}$ Judging from the internal interests of the legal system itself, the argument for integrity is understandable. But the law is not an end in itself. Law is a tool for humans. It is a tool to serve human needs. In this sense, the legal system's isolation from the various social institutions around it harms human needs. The law quickly becomes a selfish institution and no longer serves society. ${ }^{18}$

From Nonet and Selznick's perspective on reactive law, the author will then relate it to the Indonesian government and the DPR's omnibus law policy so that the meaning of this omnibus law can be studied in depth both in language and understanding. The word Omnibus comes from Latin and means for everyone. When used in conjunction with the word law, it can be defined as the law for all. According to some experts, the omnibus law is defined as a law that aims to solve significant problems in a country to repeal or change a law. ${ }^{19}$ This is a concept of a legal product used to combine various subjects, materials, subjects, and laws and regulations in various fields, into a broad and holistic legal product. The establishment of an omnibus law concerning a responsive legal model requires some prerequisites, including the completion of problematic regulatory surveys. In investing, granting investment licenses is a subsystem of the investment law. A sub-license subsystem includes functions, licensor approval, the scope of approval, procedures, and penalties. The investment permit function should not be used as a source of income but as a controller, director, community engineer for the written legal coordination process related to philosophical and sociological, economic, and legal values.

For example, as an analytical material, we can reflect on America, which implemented the Omnibus law to improve its trade deficit by making OCTA (Omnibus Trade and Competitiveness Act of 1988). The law seeks to negotiate a reciprocal trade agreement (Uruguay Round) by revising the overall trade law, adjusting support, promoting exports, adjusting tariffs, international trade policies, agricultural and telecommunications trade, international technology trade, political competitiveness and practice, corruption abroad, public procurement, patent policy, Sematech and budget deficits. With this OCTA, all these

\footnotetext{
${ }^{16}$ Agnes Fitryantica, "Harmonisasi Peraturan Perundang-Undangan Indonesia Melalui Konsep Omnibus Law," Gema Keadilan 6, no. 3 (December 14, 2019): 300-316, https://doi.org/10.14710/GK.6.3.300-316.

${ }^{17}$ A.Mukthie Fadjar, Teori-Teori Hukum Kontemporer, Setara Press, Malang, 2003, pg. 54.

${ }^{18}$ Philippe Nonet \& Philip Selznick, Hukum Responsif, Pilihan di Masa Transisi. Penerjemah Rafael Edy Bosco, Ford FoundationHuMa, Jakarta, 2003.

19 Firman Freaddy Busroh, "KONSEPTUALISASI OMNIBUS LAW DALAM MENYELESAIKAN PERMASALAHAN REGULASI PERTANAHAN,” Arena Hukum 10, no. 2 (August 1, 2017): 227-50, https://doi.org/10.21776/ub.arenahukum.2017.01002.4.
} 
rules are put together under one roof. ${ }^{20}$ Review of draft laws and regulations in various aspects, reflecting the harmony and compliance with other laws and regulations, unwritten laws that live in society, international conventions and agreements, bilateral and multilateral, which have been ratified by Indonesia. ${ }^{21}$

Besides, the balance of various interests, including the balance of interests between individuals and authorities, through the administration of governmental organizations, civil government, business activities, and social life, is reflected in the contents of the second and fourth paragraphs of the business. Regulated in the Preamble to the 1945 Constitution, the national legal system's coordination is an "indispensable prerequisite" to guarantee law enforcement and legal protection with the essence of justice and truth legal theory in Indonesia. Legal standing is not regulated in the concept of the omnibus law. Laws derived from the concept of omnibus law can lead to laws that can regulate globally and then have power over other rules (framework law). However, Indonesia does not comply with the Law Framework because all laws must be ratified in Law no. 12 of 2011 concerning the enactment of the law, amended by Law no. 15 of 2019. One party called for the improvement and refinement of overlapping laws and regulations. It is urgent in Indonesia to solve all the problems of investor reluctance to invest in Indonesia. One of them is about licensing. The discourse on implementing regulatory reform with the concept of the omnibus law, manifested in the form of integrated rules (Omnibus Ordinance), will minimize conflicts inlaws and regulations in several regions expected to facilitate investment. According to David Osborn and Ted Gaebler, future governments should focus only on control or regulation. The proposed work and service mechanisms should be kept as simple as possible in terms of procedures, speed, and low cost. ${ }^{22}$ By applying this theory, we avoid that too bureaucratic licensing violates public service principles and is burdensome. To achieve the ideals of legal work in achieving national goals, institutions need guidance in goals. Its purpose is to set a critique standard for predetermined actions and thereby open up opportunities for change. At the same time, if they are used as guidelines, targets can control the organizers' wisdom to reduce the risk of a more peaceful institution. ${ }^{23}$ On the other hand, aimlessness is rooted in rigidity and opportunism. Therefore, adaptive law assumes that objectives can be objective enough and strong enough to drive adaptive rule formation. ${ }^{24}$

Because competence as a function serves as a critical norm, the reactive legal order emphasizes: (1) substantive justice as the basis for legal validity, (2) regulation is a subordination of principles and guidelines, (3) legal considerations must be adequately focused, community co-ordinated goals and consequences, (4) the use of discretion is highly recommended for making legal decisions while remaining focused on the objectives, (5) promoting a system of liability rather than a system of coercion, (6) based on morality in cooperation as a moral principle of law enforcement, (7) power is used to support the vitality of the law in serving society, (8) rejection of the law should be seen as a challenge to legal

\footnotetext{
20 David E. Birenbaum, “The Omnibus Trade Act Of 1988: Trade Law Dialectics", <https://www.law.upenn.edu/journals/jil/article s/volume10/issue4/Birenbaum10U.Pa.J.Int\%271Bu sL653\%281988\%29.pdf>,

${ }^{21}$ Moh Hasan Wargakusumah,dkk., Perumusan Harmonisasi Hukum Tentang Metodologi Harmonisasi Hukum, BPHN Depertemen Kehakiman, Jakarta, 1996/1997, pg. 37

${ }^{22}$ Agnes Fitryantica, Op.Cit., pg. 33

${ }^{23}$ Ima Mayasari, "KEBIJAKAN REFORMASI REGULASI MELALUI IMPLEMENTASI OMNIBUS LAW DI INDONESIA," Jurnal Rechts Vinding: Media Pembinaan Hukum Nasional 9, no. 1 (April 27, 2020): 1, https://doi.org/10.33331/rechtsvinding.v9i1.401.

${ }^{24}$ Philippe Nonet \& Philip Selznick, Op.Cit., pg. 62.
} 
legitimacy, (9) access to public participation is linked to the union of legal and social representatives broad. ${ }^{25}$

In applying the omnibus law, the concept of the right to react by its nature can be used as a reference. About affirming national ambitions, at least social change and social justice requires a responsive legal system. This response can be interpreted as responding to social needs and interests experienced and confirmed by the officer and the person. The obligation to present it authentically requires special measures to enable it. Therefore, a new participatory method is needed. A responsive institution firmly maintains the essential elements of integrity while continuously monitoring or considering new forces around it. To achieve this, reactive law reinforces how openness and integrity can support each other despite conflicts between the two. This responsive institution sees sources of knowledge and opportunities for selfcorrection under social pressure. ${ }^{26}$

Therefore, the government must pay attention to the substance of the laws formulated in it. Because our country's constitution explains how our country is reflected in the nation's former founders' rules, the country's ambition and hopes to become an independent nation are expressed through the Indonesian constitution. The concept of harmonizing government legal norms through the omnibus law must at least find a hierarchical basis for our constitution's contents to maintain the spirit of state administration when the government implements a legal omnibus policy, to the extent that the author has made it.

\section{Omnibus Law, the Principle of Equity, and Economic in Indonesia}

Indonesia, The Republic of Indonesia's commitment to the law, is regulated in Article 1.3 of the 1945 Constitution. The consequence of this provision is that every attitude, policy, and behavior of the state and society must be determined by law. This provision is intended to prevent arbitrariness and arrogance of power, whether perpetrated by state officials or residents. ${ }^{27}$ An understanding of the legal rules stipulated in the provisions of article 1 paragraph 3 is closely related to the welfare state or understanding of the substantive legal rules in the tone of the fourth paragraph regarding transparency and the provisions of Article 34 of the Achievement of the state based on Pancasila support and accelerate the welfare state in Indonesia which aims to create a life that is peaceful, peaceful, prosperous and orderly in our country, where the legal position of every citizen is guaranteed so that harmony, balance, and harmony can be achieved. Individual and collective (community) interests.

The rule of law must be based on reasonable and fair law without discrimination. Good law is a democratic law based on the people's will in line with the people's sense of justice. Whereas only by law, law is intended to fulfill law's purposes and objectives, namely justice. In a government, laws, and regulations play a significant role in ensuring people's lives' articulation. Indonesia is a country with an extraordinary diversity. Many ethnicities and religions coexist. Of course, it is not easy for the government to determine the flow of laws that will be formed and enforced in a pluralistic society like Indonesia. ${ }^{28}$

Suppose we relate it to the theory put forward by Roscoe Pound, which offers a legal theory as a social engineering tool, an idea of a theory of the law's effectiveness and validity. In that case, this means that we can infer similar laws or regulations with the multifunctional tools used to achieve government goals. Currently, our country is engaged in big ideas about

\footnotetext{
25 Ibid.....pg 66.

26 Sulaiman, Hukum Responsif: Hukum Sebagai Institusi Sosial Melayani Kebutuhan Sosial Dalam Masa Transisi, https://repository.unimal.ac.id/1744/1/Hukum\%20Responsif\%20Sulaiman.pdf.

27 Eddie siregar, Undang-undang dasar negara republik Indonesia dan ketetapan majelis permusyawaratan Indonesia, (Jakarta, Sekretriat Jendral MPR RI 2015).

28 Harsono, "PROBLEMATIKA OMNIBUS LAW CIPTA LAPANGAN KERJA DI MASA PANDEMI COVID 19 (Antara Impian Dan Harapan Pemerintah Indonesia)," Al Qodiri : Jurnal Pendidikan, Sosial Dan Keagamaan 18, no. 3 (January 3, 2021): 594-603, https://doi.org/10.1234/AL QODIRI.V18I3.4057.
} 
the concept of law and legislation, which, according to the author, will change the structure of public policy in this republic. The big idea is omnibus law, the meaning of omnibus law, in general, is the simplification of legal regulations that have an impact on various areas of regulation in different contexts with existing regulations. Before discussing in detail, the author will first explain the basic rules of the upstream, which are the basis for applying or training and validating the omnibus law.

In a concrete concept, collaborative law is expected to be a method in the legal process or the formulation of regulations and not a type of legislation. Therefore, forming a legislative institution is by Law no. 12 of 2011, amended by Law no. 15 of $2019 .^{29}$ The concept of omnibus law is a legal concept used in countries that comply with the standard law system, such as the United States, when setting rules or guidelines. The rule in this concept is to make new laws to change several laws simultaneously. This discourse continues to develop because there are too many overlapping rules or regulations. With this concept, the Omnibus law is currently seen as the right solution to improve the regulatory system.

However, because the Omnibus Law (RUU) has advantages and disadvantages, it is considered inconsistent with the legal system in force in Indonesia. Law No. 12 of 2011 concerning the formation of legal regulations does not regulate collective legislation. Indonesia does not comply with the legal framework because all laws are equal. Law, which is derived from the concept of collective rights, can lead to a legal umbrella because it regulates profoundly and then rules over other rules. This makes the laws of a collective nature as rules appear to be enforced in parliament by the government. This is made possible by the amendment of Law Number 15 of 2019, which amends Law Number 12 of 2011 concerning the Formation of Legal Regulations. ${ }^{30}$

According to Jimmy Z. Usfunan, a constitutional law expert, it is necessary to look at the extent of the general framework's provisions or the details of legal provisions such as common law. Although they are general in nature, not all provisions are revoked, only the opposite. However, if the provisions are general, it becomes a problem if they conflict with the principle that the Specialist takes precedence over Lex Degorat Legi Generalis (special rules have general rules). Therefore, it must be regulated according to its position in the legal hierarchy to clear the legal principles. Legal principles are the basis or essence of truth, which are then used as the basis for reflection contained in concrete law or outside the rules of concrete legislation. General Principles of Law in Indonesia "Lex Posterior Degorat Legi Priori" is a new law that will abolish the old rule. The second is "Lex Specialis Degorat Lex Generali", specific laws can apply to general laws and regulations. The third is "Lex Superior Derogat Legi Inferior Override occurs", which is higher laws and regulations than lower laws. If this is implemented, it will cause new problems/conflicts due to conflicts between laws and regulations, even though this omnibus law brings together similar rules. This does not rule out the possibility of substantial legal uncertainty because the principle of validity becomes less clear because of the unification of the same objects. ${ }^{31}$

The government defines this collective action as an effort to simplify regulatory restrictions that are often complex and time-consuming and can improve Indonesia's investment ecosystem and competitiveness in the face of global economic uncertainty and slowdown. The regions do not automatically accept the central desire to increase investment

\footnotetext{
29 Suwandi Arham, Ahmad Saleh, and Kata Kunci, "Omnibus Law Dalam Perspektif Hukum Indonesia," PETITUM 7, no. 2 (October 31, 2019): 72-81, https://doi.org/10.1234/jh.v7i2\%20Oktober.652.

${ }^{30}$ Ibid.....hlm. 76.

31 Bayu Jati Jatmika, "ASAS HUKUM SEBAGAI PENGOBAT HUKUM; IMPLIKASI PENERAPAN OMNIBUS LAW," JAAKFE UNTAN (Jurnal Audit Dan Akuntansi Fakultas Ekonomi Universitas Tanjungpura) 9, no. 1 (July 2, 2020), https://doi.org/10.26418/jaakfe.v9i1.41145.
} 
because it can reduce the local community's cultural value. This means that the role of regional autonomy is very dominant in the regions' readiness to manage their regions. An integrated one-stop service is slowly improving this, so collective action may not be required to facilitate central and local licensing systems. Collaborative law seems authoritarian because one law can eliminate all other laws, while each region's legal culture is very different. This collaborative law consists of two main actions: the law on job creation and the tax law; if the primary purpose of the omnibus law is to strengthen and improve the investment ecosystem, it is necessary to reform investment law, commercial and business law.

The government acknowledges that the Indonesian economy is expected to grow 5.7\% per year during the 2016-2045 period to realize Indonesia's 2045 vision by carrying out structural reforms, building demographic bonuses, advancing technology, and increasing economic competitiveness. This vision must address the problem of excessive regulation in Indonesia. Bureaucracies have long slowed the country's growth and discouraged foreign investment. Sammel Gesetz can be used, everyday high to experience, free for part of the complex and man-made excessive regulatory environment of rationalized states. Management will be opened in 11 different administrative lockers, including labor laws, investment, business permits, business center, and earthworks. ${ }^{32}$ In other words, the presentation of this company was carried out by Indonesia so that international companies and investors have several attractive tourist destinations (Jong, 2020), "Weil sich die Pandemie Covid-19- im zweiten Quartal 2020 negativ auf das nationale Wirtschaftswachstum di Indonesia auswirkte". The Indonesian Union's inflation rate in the second quarter of 2020 was $5.32 \%$, compared to the first quarter of 2020 of $2.97 \%$. The youngest Rückgang is located on the equator with the support of the World Trade Organization Covid-19 and a large organization in the form of international social services for international exchange rates. Through a policy mix, Bank Indonesia is in partnership with the registration and exchange of additional rights to ensure economic security, safeguards, and encouragement of financial assistance to be established.

Companies in service are on the auxiliary website on all components of BIP securities (Widjanarko, 2020). The increase in private housing prices in the first quarter of 2020 was $5.51 \%$, compared to a positive $2.83 \%$. However, investment increased $8.61 \%$, up $1.70 \%$ in the previous period. Pengumuman statistik tertinggi di pasar dengan tren nasional diperkirakan akan meningkat, sedangkan imbal hasil wajib dari 6,90\% meningkat menjadi 3,75\% pada kuartal pertama tahun 2020, there will be an increase in exports of $11.66 \%$. Rückgang im Berichtszeitraum aufgrund der schrumpfenden Weltwirtschaft und sinkender internationaler Rohstoffpreise. Inland entrepreneurs and export market share for imports in the period region was $16.96 \%$. All business sectors with information and communication expansion will be completed in the second quarter of 2020; Water supply; Business, education and financial services; and land economy. ${ }^{33}$ The economic supply chain is mainly supported by the transportation and handling, handling and processing, and production of products. The information sector and the communication sector provide vital support in the field with various digital media responses to the Work From Home (WFH) and School From Home (SFH) Protocols. Darüber hinaus wird der Agrarsektor von der laufenden Erntesaison angetrieben.

Thus, the right steps might be to reform and strengthen the real economy, regulate fair market competition without monopoly and simplify the tax system. Recession and economic uncertainty occur because the financial, economic system is difficult to predict due to the

\footnotetext{
32 Vincent Suriadinata, "PENYUSUNAN UNDANG-UNDANG DI BIDANG INVESTASI: KAJIAN PEMBENTUKAN OMNIBUS LAW DI INDONESIA," Refleksi Hukum: Jurnal Ilmu Hukum 4, no. 1 (December 22, 2019): 115-32, https://doi.org/10.24246/jrh.2019.v4.i1.p115-132.

${ }^{33}$ Onny Widjanarko, Government Press Release. https://www.bi.go.id/en/iru/government-pressrelease/Pages/National-Economic-Growth-Impacted-by- COVID-19-in-Q2-2020.aspx.
} 
global economic slowdown. Because in fact, the Omnibus law has several points that are still pros and cons. Related to business licensing simplification. Every business in Indonesia now requires one or more licenses to operate, and many of them have to be renewed after a certain period. The responsibilities for issuing business licenses are spread across many government agencies, both central and local governments. This multi-layered system, which involves various agencies, makes it difficult for investors to know what business licenses to obtain, where to get them, and how to apply them.

The law that is made must be in line with society's demands, the real needs of the times in people's lives, which are considered urgent to be regulated in positive law. This means when this positive law can apply sociologically (because society needs it) and apply philosophically (because society views it needs to be regulated). The era of the industrial revolution 4.0 was marked by the development of technology that made various transactions easier. However, it also needs to be watched out for because the more advanced the technology, the more human civilization will retreat. After all, technology's facilities impact the shifting of civilization values in economic and trade transactions. In the era of globalization, there are many arrangements and relationships between individuals (in the field of civil law) that are managed by technology, information, and communication. Even various forms of agreement that were previously carried out face-to-face have now shifted people to no longer meet face to face in giving birth to a contract or transaction. So that cyberspace has become an intermediary that is faster in giving birth to electronic transactions between parties. In the view of legal realism (mostly progressive legal thinking), it is always understood and understood that the law is wobbling behind reality (het rech hint ancther). ${ }^{34}$

This causes the law to be more racing (trying to run fast) in making adjustments to the development and behavior of human life. It is not wrong that the law in modern circles is always required to reflect on the rules born from these human habits in behaving as the law is always said to be the development of the soul of a nation (volkgeist). Thus, the state must stipulate the regulation into positive law, so that the regulation applies juridically. When it is formed or when it is applied in a concrete case in the field, positive law will touch on the factors of time and space. The spatial factor indicates where (location) the legal subjects are and interact with others and their surroundings. The time factor indicates a certain period when this legal subject is alive and active. These two factors frame human activity as individual and social beings so that these space and time factors can shape the behavior patterns of community members.

Customs and habits are examples of the behavior patterns of people who are in the same room at a particular time. It is this similarity that shapes culture. Therefore, it is necessary to form a legal culture first before applying a new legal rule. Moreover, the presence of this omnibus law indirectly uniforms laws into one, but not all laws can be uninformed because each region must have a different legal culture. Because if the only investment is the primary basis for this omnibus law's birth, it will reap a process because the investment is considered to diminish the local culture directly or indirectly. It was there that various protests arose when a new regulation was born or was not under the local legal culture. Therefore, regional autonomy is one of the efforts to establish a legal culture in the region.

\section{Conclusion}

\footnotetext{
${ }^{34}$ Andri Winjaya Laksana, “ Omnibus Law Opportunities And Challenges Towards Entrepreneurs And Labor : Comparative Review Law” THE 1 St PROCEEDING International Conference And Call Paper, The 1st Proceeding International Conference And Call Paper, vol. 1, 2020, www.apic.unissula.ac.id.
} 
The Republic of Indonesia as a constitutional state is stated in the 1945 Constitution article 1 paragraph 3 . The consequence of this provision is that every attitude, policy, and behavior of the state and population must be based on and under the law. At the same time, this provision is intended to prevent arbitrariness and arrogance of power, whether perpetrated by state officials or by residents. The understanding of a constitutional state as stated in the provisions of article 1 paragraph 3 is closely related to the welfare state or understanding of the state law material by the sound of the fourth paragraph of the opening and the provisions of article 34 of the 1945 Constitution of the Republic of Indonesia. A state-based on law must be based on reasonable and fair laws without discrimination based on Pancasila. In the perspective of responsive law that there are several competencies as an objective to function as a critical norm, then the responsive legal order emphasizes: (1) 'Substantive justice as a basis for legal legitimacy, (2) Regulation is a sub-ordination of principles and policies, (3) Legal considerations must be objective and consequential for the benefit of society, (4) the use of discretion is highly recommended in legal decision making while remaining oriented towards the destination, (5) Fostering a system of obligations as a substitute for a system of coercion, (6) Morality of cooperation as a moral principle in carrying out the law, (7) power is used to support the vitality of the law in serving society, (8) Rejection of the law must be seen as a challenge to legal legitimacy, (9) Access to public participation is widely opened in the context of integrating legal and social advocacy. In Indonesia, recently, we have been shocked by executives' legal politics to improve the economy so that the Job Creation Law with the concept of Omnibus Law was born. Omnibus law is a new thing in the field of laws and regulations of the Republic of Indonesia. In addition to the fact that our country's legal system adheres to Civil Law, it is also in the hierarchy/order of laws and regulations in Indonesia that has not included the concept of omnibus law as one of the principles in the source of law. However, the law that will later be generated from the omnibus law concept can lead to the Omnibus Law because it regulates thoroughly and then has powers over other rules. However, in Indonesia, it does not adhere to the Umbrella Law because all laws' position is the same. Their position must be given legitimacy in Law Number 12 of 2011, which requires amendments. Also, it is necessary to carry out an inventory of problems related to comprehensive and in-depth investments. All aspects related to investment are understood so that there will be no confusion or even a legal vacuum in the future because there is no legal instrument that regulates specific issues.

\section{A. Books}

\section{Bibliography}

Soekanto, Soerjono dan Sri Mamudji, Penelitian Hukum Normatif: Suatu Tinjauan Singkat, Cet. 8. Jakarta: PT RajaGrafindo Persada, 2006.

Ibrahim, Johny, Teori dan Metodologi Penelitian Hukum Normatif, Malang: Bayumedia Publishing, 2006.

Fadjar, A.Mukthie, Teori-Teori Hukum Kontemporer, Malang: Setara Press. 2003.

Philippe Nonet \& Philip Selznick, Hukum Responsif, Pilihan di Masa Transisi. Penerjemah Rafael Edy Bosco, Ford FoundationHuMa, Jakarta, 2003.

Wargakusumah, Moh Hasan, dkk, Perumusan Harmonisasi Hukum Tentang Metodologi Harmonisasi Hukum, Jakarta: BPHN Depertemen Kehakiman. 1996.

\section{B. Journal}

Andri Winjaya Laksana. “ Omnibus Law Opportunities And Challenges Towards Entrepreneurs And Labor: Comparative Review Law” THE 1 St PROCEEDING International Conference And Call Paper. The 1st Proceeding International Conference And Call Paper. Vol. 1, 2020. www.apic.unissula.ac.id. 
Arham, Suwandi, Ahmad Saleh, and Kata Kunci. "Omnibus Law Dalam Perspektif Hukum Indonesia." PETITUM 7, no. 2 (October 31, 2019): 72-81. https://doi.org/10.1234/jh.v7i2\%20Oktober.652.

Busroh, Firman Freaddy. "KONSEPTUALISASI OMNIBUS LAW DALAM MENYELESAIKAN PERMASALAHAN REGULASI PERTANAHAN.” Arena Hukum 10, no. 2 (August 2017 ): 2 https://doi.org/10.21776/ub.arenahukum.2017.01002.4.

Donald, Henry, and Lbn Toruan. "PEMBENTUKAN REGULASI BADAN USAHA DENGAN MODEL OMNIBUS LAW." To-Ra. Vol. 3, May 16, 2017. http://katadata.co.id/berita/2017/05/09/jelang.

Fitryantica, Agnes. "Harmonisasi Peraturan Perundang-Undangan Indonesia Melalui Konsep Omnibus Law." Gema Keadilan 6, no. 3 (December 14, 2019): 300-316. https://doi.org/10.14710/GK.6.3.300-316.

Harsono. "PROBLEMATIKA OMNIBUS LAW CIPTA LAPANGAN KERJA DI MASA PANDEMI COVID 19 (Antara Impian Dan Harapan Pemerintah Indonesia)." Al Qodiri : Jurnal Pendidikan, Sosial Dan Keagamaan 18, no. 3 (January 3, 2021): 594-603. https://doi.org/10.1234/AL QODIRI.V18I3.4057.

Jatmika, Bayu Jati. "ASAS HUKUM SEBAGAI PENGOBAT HUKUM; IMPLIKASI PENERAPAN OMNIBUS LAW." JAAKFE UNTAN (Jurnal Audit Dan Akuntansi Fakultas Ekonomi Universitas Tanjungpura) 9, no. 1 (July 2, 2020). https://doi.org/10.26418/jaakfe.v9i1.41145.

Mayasari, Ima. "KEBIJAKAN REFORMASI REGULASI MELALUI IMPLEMENTASI OMNIBUS LAW DI INDONESIA." Jurnal Rechts Vinding: Media Pembinaan Hukum Nasional 9, no. 1 (April 27, 2020): 1. https://doi.org/10.33331/rechtsvinding.v9i1.401.

Orinaldi, Mohammad. "Relasi Antara Omnibus Law Di Era Pandemi Covid-19 Dan Perekonomian Di Indonesia." Jurnal Manajemen Dan Sains 5, no. 2 (2020): 269-75. https://doi.org/10.33087/jmas.v5i2.194.

Prabowo, Adhi Setyo, Andhika Nugraha Triputra, and Yoyok Junaidi. "Politik Hukum Omnibus Law Di Indonesia." Pamator Journal 13, no. 1 (April 4, 2020): 1-6. https://doi.org/10.21107/pamator.v13i1.6923.

Putra Antoni. "PENERAPAN OMNIBUS LAW DALAM UPAYA REFORMASI REGULASI." Legislasi Indonesia 17, no. $1 \quad$ (2020). https://ejurnal.peraturan.go.id/index.php/jli/article/view/602.

Setiadi, Wicipto. "SIMPLIFIKASI REGULASI DENGAN MENGGUNAKAN METODE PENDEKATAN OMNIBUS LAW." Jurnal Rechts Vinding: Media Pembinaan Hukum Nasional 9, no. 1 (April 27, 2020): 39. https://doi.org/10.33331/rechtsvinding.v9i1.408.

Suriadinata, Vincent. "PENYUSUNAN UNDANG-UNDANG DI BIDANG INVESTASI: KAJIAN PEMBENTUKAN OMNIBUS LAW DI INDONESIA." Refleksi Hukum: Jurnal Ilmu Hukum 4, no. 1 (December 22, 2019): 115-32. https://doi.org/10.24246/jrh.2019.v4.i1.p115-132.

Ulil, Ahmad, Sakti Lazuardi, and Ditta Chandra Putri. "Arsitektur Penerapan Omnibus Law Melalui Transplantasi Hukum Nasional Pembentukan Undang-Undang." Jurnal Ilmiah Kebijakan Hukum 14, no. 1 (March 27, 2020): 1. https://doi.org/10.30641/kebijakan.2020.v14.1-18.

Utomo, Pudjo. "Omnibus Law : Dalam Perspektif Hukum Responsif." Nurani Hukum 2, no. 1 (May 18, 2020): 33. https://doi.org/10.51825/nhk.v2i1.8168.

\section{Internet}


Gesuri.id, 5 prioritas kerja Jokowi-Ma'kruf, di akses di https://www.gesuri.id/grafis/5prioritas-kerja-jokowi-ma-ruf-b1WovZnDw, on November 6, 2020 at 15:45.

Kompas.com, "Mengenal Omnibus Law yang akan dibahas pemerintah dan DPR..." https://nasional.kompas.com/read/2019/11/29/13511951/mengenal-omnibus-lawyang-akan- dibahas-pemerintah-dan-dpr?page=all. On the week of January 24, 2021 at 05:32.

Mochamad Januar Rizki, "Menyoal Ide Omnibus Law dalam Pidato Pelantikan Jokowi," https://www.hukumonline.com/berita/baca/lt5dadb8e0be9fc/menyoal-ideomnibus-law-dalam-pidato-pelantikan-jokowi, on Sunday January 24, 2021.Greenhourse, What Foreighn Investors Need to Know About Indonesia's Proposed Omnibus Law. https://greenhouse.co/blog/omnibus-law-indonesia/, on January 25, 2020.

Lath, Vivek., Tracy Lee., Khoon Tee Tan., \& Phillia Wibowo. 2020. Despite the Social and Economic Uncertainty and Advance Its Economy and Prepare for Strong Postcrisis Emergence. https://www.mckinsey.com/featured-insights/asiapacific/with-effort-indonesia-can-emerge-from-the-covid- 19-crisis-stronger, on 25 January 2020.

David E. Birenbaum, "The Omnibus Trade Act Of 1988: Trade Law Dialectics", https://www.law.upenn.edu/journals/jil/article s/volume10/issue4/Birenbaum10U.Pa.J.Int\%271Bu sL653\%281988\%29.pdf

Sulaiman, Hukum Responsif: Hukum Sebagai Institusi Sosial Melayani Kebutuhan Sosial Dalam https://repository.unimal.ac.id/1744/1/Hukum\%20Responsif\%20Sulaiman.pdf. 
